\title{
Perbandingan Pergerakan Titik Pantau Deformasi Kepulauan Sangihe Menggunakan Metode Perhitungan Periodik dan Simultan Berdasarkan Data GNSS Tahun 2014, 2015, dan 2016
}

\author{
The Comparison of Sangihe Islands Deformation Monitoring Point Movement Using Periodic and \\ Simultaneous GNSS Processing Data Methods Based on 2014, 2015, and 2016 Epochs Data
}

\author{
Muhammad Arsyad Fauzi ${ }^{1}$, Leni Sophia Heliani ${ }^{2}$ \\ 1 Alumni Departemen Teknik Geodesi FT-UGM, Indonesia \\ 2 Staf Pengajar Departemen Teknik Geodesi FT-UGM, Indonesia
}

Penulis Korespondensi: Leni Sophia Heliani | Email: lheliani@ugm.ac.id

\begin{abstract}
ABSTRAK
Studi pergerakan titik pantau deformasi Kepulauan Sangihe telah dilakukan dengan metode pengukuran GNSS. Salah satu faktor yang menentukan ketelitian titik pantau deformasi yaitu metode pengolahan data yang digunakan. Oleh karena itu, penelitian ini mengkaji perbandingan kecepatan pergerakan titik pantau deformasi Kepulauan Sangihe menggunakan pengolahan data GNSS secara periodik dan simultan. Penelitian ini menggunakan tiga kala pengamatan, yaitu 2014, 2015, dan 2016. Data pengamatan diolah dengan perangkat lunak GAMIT/GLOBK yang diikatkan terhadap ITRF 2014 sehingga menghasilkan koordinat dan ketelitiannya. Berdasarkan data koordinat dan ketelitiannya, dilakukan perhitungan kecepatan pergerakan beserta ketelitiannya menggunakan metode periodik dan simultan. Berdasarkan metode periodik, kecepatan pergerakan titik SGH1 pada komponen N sebesar $-1,11 \pm$ 2,72 mm/tahun, pada komponen E sebesar 9,21 $\pm 4,17 \mathrm{~mm} /$ tahun, dan pada komponen U sebesar $-15,02 \pm 50,64 \mathrm{~mm} /$ tahun, sedangkan kecepatan pergerakan titik SGH3 pada komponen $\mathrm{N}$ sebesar $-4,93 \pm 1,56 \mathrm{~mm} /$ tahun, pada komponen E sebesar $16,50 \pm$ 2,47 mm/tahun, dan pada komponen U sebesar $-6,69 \pm 19,42 \mathrm{~mm} /$ tahun. Berdasarkan metode simultan, kecepatan pergerakan titik SGH1 pada komponen N sebesar -1,56 $\pm 1,25 \mathrm{~mm} /$ tahun, pada komponen E sebesar 9,40 $\pm 1,55 \mathrm{~mm} /$ tahun, dan komponen U sebesar $-11,54 \pm 5,83 \mathrm{~mm} /$ tahun, sedangkan kecepatan pergerakan titik SGH3 pada komponen N sebesar $-5,18 \pm 0,88 \mathrm{~mm} /$ tahun, pada komponen E sebesar 16,91 \pm 1,10 mm/tahun, dan pada komponen U sebesar -2,84 $\pm 3,49 \mathrm{~mm} /$ tahun. Penelitian ini membuktikan hipotesis bahwa perhitungan data GNSS metode simultan menghasilkan ketelitian yang lebih tinggi daripada metode periodik.
\end{abstract}

Kata Kunci: Pulau Sangihe, geodinamika, deformasi, periodik, simultan, GNSS

\section{ABSTRACT}

The study of deformation monitoring point movement of Sangihe Islands was conducted using the GNSS measurement methods. One of the factor that determines the accuracy of the deformation monitoring is the utilized data processing methods. Therefore, this research analyze the comparison of deformation monitoring point movement of Sangihe Islands using periodic and simultaneous GNSS data processing methods. This research used three observations epochs of GNSS, i.e. 2014, 2015 and 2016. The observational data were processed using GAMIT/GLOBK software that tied to ITRF 2014 to produce coordinates and their accuracy. Based on the coordinate data and its accuracy, the velocity of movements calculation and their accuracy was done using the periodic and simultaneous methods. Based on the periodic method, the velocity of the SGH1 point on the $N$ component is $-1,11 \pm 2,72 \mathrm{~mm} /$ year, on the E component is 9,21 $\pm 4,17$ $\mathrm{mm} /$ year, and on the $U$ component is $-15,02 \pm 50,64 \mathrm{~mm} /$ year, while the velocity of the SGH3 point on the N component is $-4,93 \pm 1,56$ $\mathrm{mm} /$ year, on the E component is $16,50 \pm 2,47 \mathrm{~mm} /$ year, and on the U component is $-6,69 \pm 19,42 \mathrm{~mm} /$ year. Based on the simultaneous method, the velocity of the SGH1 point on the $N$ component is $-1,56 \pm 1,25 \mathrm{~mm} /$ year, on the E component is $9,40 \pm 1,55 \mathrm{~mm} /$ year, and on the $U$ component is $-11,54 \pm 5,83 \mathrm{~mm} /$ year, while the velocity of the SGH3 point on the $N$ component is $-5,18 \pm 0,88 \mathrm{~mm} /$ year, on the $E$ component is $16,91 \pm 1,10 \mathrm{~mm} /$ year, and on the $U$ component is $-2,84 \pm 3,49 \mathrm{~mm} /$ year. This research proves the hypothesis that the simultaneous GNSS data calculation results in higher accuracy than the periodic method.

Keywords: Sangihe Islands, geodynamic, movement, periodic, simultaneous, GNSS

(C) Author(s) 2020. This is an open access article under the Creative Commons Attribution-ShareAlike 4.0 International License (CC BY-SA 4.0). 


\section{Pendahuluan}

Kabupaten Kepulauan Sangihe merupakan kepulauan terluar di bagian utara Indonesia yang terletak di antara Pulau Sulawesi dengan Pulau Mindanao (Filipina). Kabupaten Kepulauan Sangihe berada di antara dua lempeng tektonik aktif yaitu Lempeng Pasifik yang bergerak ke arah barat laut dan Lempeng Eurasia yang bergerak ke arah tenggara (Darman, 2000). Selain itu menurut Badan Perencanaan Pembangunan Daerah Kabupaten Kepulauan Sangihe, kawasan Kepulauan Sangihe merupakan daerah lintasan gunung berapi trans pasifik dari daerah Hawai, Jepang, Filipina dan berakhir di Kawasan Maluku (BAPPEDA, 2009). Hal tersebut menyebabkan Kepulauan Sangihe menjadi daerah rawan bencana alam, khususnya gempa bumi.

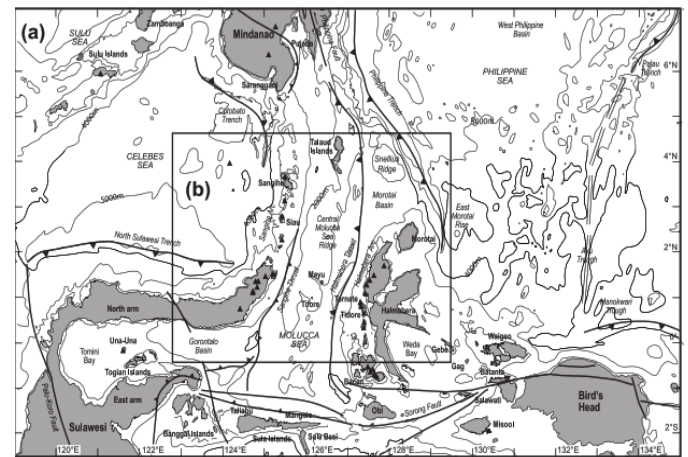

Gambar 1.1 Subduksi Kepulauan Sangihe (Jaffe, dkk, 2004)

Berdasarkan kondisi tersebut, peta potensi bencana alam dan peta jalur evakuasi bencana alam menjadi hal yang perlu dipersiapkan untuk kegiatan mitigasi bencana sehingga dapat meminimalisir korban jiwa maupun kerusakan material yang ditimbulkan. Salah satu upaya untuk mendukung keberhasilan mitigasi bencana yaitu melakukan studi geodinamika dengan metode survei Global Navigation Satellite System (GNSS) (Manfré dkk., 2012).

Mulai tahun 2016 hingga tahun 2019 telah dilakukan beberapa penelitian menggunakan data GNSS Kepulauan Sangihe dengan metode perhitungan periodik dan simultan (Kurniawan, 2016; Nugraha, 2017; Ladivanov, 2018; Nugroho, 2019). Hasil penelitian tersebut menunjukkan masing-masing titik pantau bergerak ke arah tenggara dengan kecepatan antara 9,6 mm/tahun hingga $19,04 \mathrm{~mm} /$ tahun. Deteksi pergerakan lempeng tektonik yang nilai pegerakannya kecil seperti pada kasus Kepulauan Sangihe memerlukan survei GNSS. Survei GNSS dilakukan agar menghasilkan ketelitian yang tinggi pada setiap nilai koordinat titik pantau. Ketelitian posisi yang didapat dengan pengamatan GNSS secara umum bergantung pada empat faktor yaitu metode penentuan posisi yang digunakan, geometri dan distribusi dari satelitsatelit yang diamati, ketelitian data yang digunakan, dan metode pengolahan data yang diterapkan (Abidin, 2000).
Metode pengolahan data yang diterapkan merupakan salah satu faktor penting untuk menghasilkan ketelitian yang optimal. Diantara beberapa metode yang biasa digunakan untuk pengolahan data GNSS yaitu metode perhitungan kecepatan pergerakan secara periodik dan simultan. Metode periodik merupakan perhitungan kecepatan pergerakan per kala pengamatan, sedangkan metode simultan merupakan perhitungan kecepatan pergerakan menggunakan keseluruhan kala pengamatan secara serentak. Oleh karena itu, perlu dilakukan berbagai metode pengolahan data agar diperoleh metode pengolahan data yang paling optimal untuk studi geodinamika. Penelitian ini mengkaji perbandingan kecepatan pergerakan titik pantau deformasi Kepulauan Sangihe menggunakan metode pengolahan data GNSS secara periodik dan simultan berdasarkan kala pengamatan tahun 2014, 2015, dan 2016.

\section{Data dan Metodologi}

\subsection{Data dan Lokasi}

Penelitian ini dilakukan menggunakan tiga titik pantau yang tersebar di Kabupaten Kepulauan Sangihe, Sulawesi Utara. Tiga titik pantau tersebut yaitu: SGH1 terletak di Kelurahan Kolongan Mitung, Kecamatan Tahuna Barat, SGH3 terletak di Desa Mohongsawang, Kecamatan Kendahe, dan SGH4 terletak di Desa Bebalang, Kecamatan Manganitu Selatan.

Data yang digunakan dalam penelitian ini terdiri atas data utama dan data pendukung. Data utama dalam penelitian ini yaitu:

1. Data pengukuran titik pantau GNSS dalam format jps. Data pengukuran ini terdiri atas tiga kala pengamatan, yaitu data pengamatan tahun 2014, 2015, dan 2016. Kala pengamatan tahun 2014 menggunakan titik pantau SGH1 dan SGH3 yang terdiri atas empat day of years (doy), yaitu doy 231 s.d. 234. Kala pengamatan tahun 2015 menggunakan titik pantau SGH1, SGH3, dan SGH4 yang terdiri atas dua doy, yaitu doy 218 dan 219. Sedangkan kala pengamatan tahun 2016 menggunakan titik pantau SGH1, SGH3, dan SGH4 yang terdiri atas empat doy, yaitu doy 218 s.d. 221. Sampling rate semua data tersebut dikonversi menjadi 30 detik agar sesuai dengan data Receiver Independent Exchange Format (RINEX) pengamatan dari stasiun International GNSS Service (IGS).

2. Data RINEX pengamatan dari stasiun IGS. Data RINEX pengamatan stasiun IGS dapat diunduh dari situs http://sopac.ucsd.edu atau http://cddis.nasa.gov yang berupa data observasi untuk doy 231 s.d. 234 pada kala pengamatan 2014, doy 218 dan 219 pada kala pengamatan 2015, dan doy 218 s.d. 221 pada kala pengamatan 2016. Stasiun IGS dalam penelitian ini meliputi CCJ2, COCO, DARW, IISC, PIMO, TOW2, dan TUVA. 
3. Data precise ephemeris. Data precise ephemeris berupa data IGS final orbit untuk doy 231 s.d. 234 pada kala pengamatan 2014, doy 218 dan 219 pada kala pengamatan 2015, dan doy 218 s.d. 221 pada kala pengamatan 2016. Data ini dapat diperoleh dari situs http://sopac.ucsd.edu dengan format *.sp3.

4. Data broadcast ephemeris. Data broadcast ephemeris berupa data navigasi satelit untuk doy 231 s.d. 234 pada kala pengamatan 2014, doy 218 dan 219 pada kala pengamatan 2015, dan doy 218 s.d. 221 pada kala pengamatan 2016. Data ini dapat diperoleh dari situs http://igscb.jpl.nasa.gov dengan format *.14n, *.15n, dan*.16n.

Selanjutnya data pendukung dalam penelitian ini yaitu:

1. Data koreksi pemodelan cuaca. Data ini berisi fungsi pemetaan cuaca hitungan. Data ini dapat diperoleh dari situs http://everest.mit.edu berupa vmflgrid.2014, vmflgrid.2015, dan vmflgrid.2016.

2. Data koreksi atmosfer. Data ini berisi pemodelan delay atmosfer yang berfungsi untuk meminimalisir pengaruh bias pada troposfer. Data ini dapat diperoleh dari situs http://everest.mit.edu berupa atmdisp_cm.2014, atmdisp_cm.2015, dan atmdisp_cm.2016.

3. Data koreksi pasut. Data ini merupakan pencerminan dinamika pasang surut air laut di seluruh dunia. Data ini dapat diperoleh dari situs http://everest.mit.edu berupa OTL.FES2004.grid.

\subsection{Metodologi}

Pada penelitian ini, data raw hasil pengukuran titik pantau GNSS berupa data dengan format JPS. Data raw tersebut perlu dikonversi menjadi berkas data dengan format RINEX agar dapat diolah dengan GAMIT/GLOBK. Proses konversi dilakukan dengan perangkat lunak TEQC menghasilkan dua buah berkas RINEX yaitu navigasi dan observasi. Perangkat lunak GAMIT/GLOBK memerlukan berkas RINEX yang terpisah setiap doy dengan interval data 30 detik. Interval data dibuat 30 detik agar sesuai dengan interval stasiun IGS yang juga 30 detik.

Sebelum pengolahan dengan GAMIT/GLOBK perlu dilakukan pengecekan kualitas data RINEX stasiun pengamatan. Pengecekan kualitas data dilakukan menggunakan TEQC dengan full quality check file yaitu pengecekan kualitas data dengan melibatkan file observasi dan file navigasi. Pengecekan kualitas data menghasilkan keterangan mengenai data RINEX yang diolah seperti parameter multipath dan ionospheric delay yang terjadi saat pengamatan. Menurut Lestari (2006), data pengamatan memiliki kualitas data yang baik jika nilai parameter-parameternya memenuhi kriteria berikut :
1. Nilai MP1
$<0,5 \mathrm{~m}$
2. Nilai MP2
$<0,5 \mathrm{~m}$
3. Nilai IOD slips
$<100$
4. Nilai IOD or MP slips
$<100$

Nilai koordinat dan simpangan baku didapatkan melalui pengolahan dengan perangkat lunak GAMIT/GLOBK yang diikatkan pada ITRF 2014. Desain jaring IGS yang digunakan yaitu desain jaring rik2 sesuai penelitian Nursetiyadi (2015). Desain jaring IGS pada penelitian ini dapat dilihat pada Gambar 2.1.

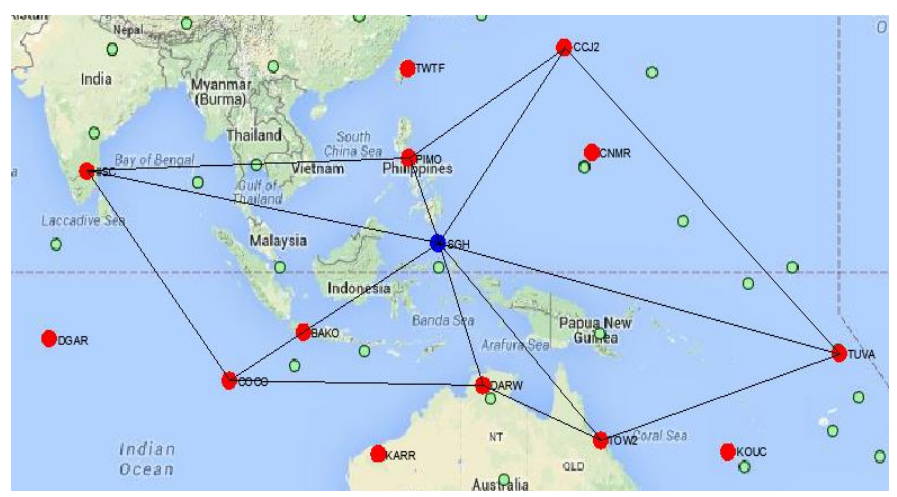

Gambar 2.1 Desain jaring IGS rik2 (Nursetiyadi, 2015)

Pengolahan menggunakan GAMIT menghasilkan panjang baseline. Perataan jaring pada GAMIT menggunakan metode double difference dan prinsip metode parameter berbobot dalam perhitungan data pseudorange dan carrier phase dengan persamaan observasi menggunakan data fase. Sebagai contoh, apabila ada dua receiver yang berada pada dua titik pengamatan $G$ dan $\mathrm{H}$, dengan vektor koordinat titik $\mathrm{G}$ dan $\mathrm{H}$ dinyatakan sebagai $\left(\mathrm{X}_{\mathrm{G}}, \mathrm{Y}_{\mathrm{G}}, \mathrm{Z}_{\mathrm{G}}\right)$ dan $\left(\mathrm{X}_{\mathrm{H}}, \mathrm{Y}_{\mathrm{H}}, \mathrm{Z}_{\mathrm{H}}\right)$. Untuk persamaan double difference, pengamatan dilakukan terhadap dua satelit yaitu a dan b, menghasilkan persamaan jarak sebagai berikut (King dan Bock, 2002) :

$$
\begin{aligned}
& \rho_{G}^{a}=\sqrt{\left[X^{a}(t)-X_{G}\right]^{2}+\left[Y^{a}(t)-Y_{G}\right]^{2}+\left[Z^{a}(t)-Z_{G}\right]^{2}} \\
& \rho_{H}^{b}=\sqrt{\left[X^{b}(t)-X_{H}\right]^{2}+\left[Y^{b}(t)-Y_{H}\right]^{2}+\left[Z^{b}(t)-Z_{H}\right]^{2}}
\end{aligned}
$$

Keterangan:

$\rho_{G}^{a} \quad$ : jarak geometri antara satelit a dengan titik G

$\rho_{H}^{b} \quad$ : jarak geometri antara satelit b dengan titik $\mathrm{H}$

Titik G memiliki koordinat pendekatan $\left(X_{G}^{0}, Y_{G}^{0}, Z_{G}^{0}\right)$ sehingga diperoleh persamaan koordinat titik G sebagai berikut:

$$
\begin{aligned}
& X_{G}=X_{G}^{0}+d X_{G} \\
& Y_{G}=Y_{G}^{0}+d Y_{G} \\
& Z_{G}=Z_{G}^{0}+d Z_{G}
\end{aligned}
$$

Keterangan:

$$
\left(d X_{G}, d Y_{G}, d Z_{G}\right) \quad \text { : koreksi posisi titik } \mathrm{G}
$$

Linierisasi dilakukan pada persamaan 1 dan 2 sehingga diperoleh persamaan 6 dan 7. Persamaan 6 merupakan hasil linierisasi persamaan 1 sedangkan persamaan 7 merupakan hasil linierisasi persamaan 2 .

$$
\begin{aligned}
& \rho_{G}^{a}(t)=\rho_{G}^{a}+c x^{a}(t) d X_{G}+c y^{a}(t) d Y_{G}+c z^{a}(t) d Z_{G} \\
& \rho_{H}^{b}(t)=\rho_{H}^{b}+c x^{b}(t) d X_{H}+c y^{b}(t) d Y_{H}+c z^{b}(t) d Z_{H}
\end{aligned}
$$


Linierisasi menghasilkan koefisien :

cx : turunan persamaan terhadap $\mathrm{dX}$

cy : turunan persamaan terhadap $d Y$

cz : turunan persamaan terhadap dZ

Dengan melakukan subtitusi persamaan 6 dan 7 ke dalam persamaan matriks residu, menghasilkan penyelesaian double difference seperti persamaan 8.

$$
\begin{aligned}
& \Delta \nabla L_{G H}{ }^{a b}(t)+\Delta \nabla r C_{G H}^{a b}(t)= \\
& \Delta \nabla \rho_{G H}{ }^{a b}(t)+\Delta \nabla c x^{a b}(t) d X_{G}+\Delta \nabla c y^{a b}(t) d Y_{G} \\
& +\Delta \nabla c z^{a b}(t) d Z_{G}-\lambda \Delta \nabla N_{G H}^{a b}
\end{aligned}
$$

Keterangan:

$$
\begin{array}{ll}
\Delta \nabla L_{G H}{ }^{a b} & \text { : besaran double difference } \\
\mathrm{C} & \text { : matriks desain double difference } \\
\rho & \text { : matriks jarak antara satelit dengan titik } \\
& \text { pengamatan } \\
\lambda & \text { : panjang gelombang sinyal pembawa }
\end{array}
$$

Persaman 8 menggunakan data beda fase. Koordinat titik A diperoleh dengan hitung kuadrat terkecil parameter berbobot. Hitung kuadrat terkecil dilakukan dengan persamaan 9 dengan bobot pada 10 .

$$
\begin{aligned}
& V=A X+L \\
& P=\left(\begin{array}{cc}
P_{1} & 0 \\
0 & P_{2}
\end{array}\right)
\end{aligned}
$$

Matriks $A, X$ dan $L$ diperoleh dengan persaman 11,12 , dan 13 sebagai berikut:

$$
\begin{aligned}
A & =\left[\nabla c x_{G H}{ }^{a b}(t) \nabla c y_{G H}{ }^{a b}(t) \nabla c z_{G H}{ }^{a b}(t)-\lambda\right] \\
L & =\left[\Delta \nabla L_{G H}{ }^{a b}(t)-\Delta \nabla \rho_{G H}{ }^{a b}(t)\right] \\
X & =\left[\begin{array}{c}
d X_{G} \\
d Y_{G} \\
d Z_{G} \\
\Delta \nabla N_{G H}
\end{array}\right]
\end{aligned}
$$

Hasil persamaan observasi yang telah dilinearisasi menjadi persamaan 14 .

$$
L^{\prime}=\left[\begin{array}{c}
X_{0}-X_{b} \\
Y_{0}-Y_{b} \\
Z_{0}-Z_{b}
\end{array}\right]
$$

Keterangan:

$$
\begin{array}{ll}
V & \text { : matriks residu, diperoleh dari persamaan } 9 \\
P & : \text { matriks bobot, diperoleh dari persamaan } 10 \\
A & \text { : matriks desain, diperoleh dari persamaan } 11 \\
L & \text { : matriks sisa, diperoleh dari persamaan } 12 \\
X & \text { : matriks parameter, diperoleh dari persamaan } 13
\end{array}
$$

Proses hitungan pada GLOBK merupakan proses Kalman Filter untuk mengkombinasikan solusi-solusi hasil pengolahan data pengamatan. Terdapat tiga program utama dalam perangkat lunak GLOBK, yaitu GLOBK,
GLRED, dan GLORG. GLOBK merupakan proses Kalman Filter untuk mengkombinasikan data pengolahan harian GAMIT dan untuk mendapatkan estimasi posisi rata-rata titik pengamatan. GLORG melakukan pengikatan titik-titik pengamatan terhadap titik-titik referensi yang diberikan. GLRED melakukan perhitungan posisi pada masingmasing hari, sehingga ketelitian posisi yang diperoleh dapat dibandingkan per waktu tertentu (Afzal, 2015).

Nilai koordinat dan simpangan baku yang didapatkan selanjutnya digunakan untuk perhitungan kecepatan pergerakan metode periodik dan simultan. Perhitungan kecepatan pergerakan metode periodik dan simultan pada penelitian ini menggunakan data GNSS yang sama, yaitu kala pengamatan 2014, 2015, dan 2016. Metode periodik merupakan perhitungan kecepatan pergerakan per kala pengamatan, sedangkan metode simultan merupakan perhitungan kecepatan pergerakan dengan keseluruhan kala pengamatan secara serentak.

Kecepatan pergerakan dan simpangan baku 2014 hingga 2016 pada metode simultan diperoleh dari hasil pengolahan dengan modul GLOBK menggunakan data kala pengamatan 2014, 2015, dan 2016 secara serentak, sedangkan kecepatan pergerakan dan simpangan baku 2014 hingga 2016 pada metode periodik diperoleh dari rata-rata kecepatan dan perambatan kesalahan data kala pengamatan 2014 - 2015 dan 2015 - 2016 hasil pengolahan dengan modul GLOBK.

Metode yang dapat digunakan untuk menghitung perambatan kesalahan dari pergerakan titik-titik pantau 3D dengan estimasi ketelitian pergerakannya (SavsekSafic, dkk., 2006 dalam Lestari, 2015). Misalkan posisi titik pada bidang per kala adalah $\mathrm{T}_{\mathrm{t}}\left(\mathrm{X}_{\mathrm{t}}, \mathrm{Y}_{\mathrm{t}}, \mathrm{Z}_{\mathrm{t}}\right)$ dan $\mathrm{T}_{(\mathrm{t}+\Delta \mathrm{t})}\left(\mathrm{X}_{(\mathrm{t}+\Delta \mathrm{t}) \text {, }}\right.$

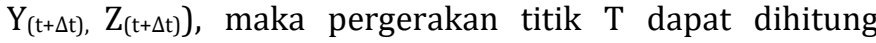
dengan persamaan 15 menggunakan konsep jarak antar dua buah posisi. Sementara untuk varian kovarian pergerakan titik $\mathrm{T}$ ditentukan menggunakan persamaan perambatan kesalahan seperti yang dimodelkan pada persaman 16. Ketelitian pergerakan ditunjukkan oleh nilai varian kovarian pergerakan ( $\Sigma_{d d}$ ). Akar elemen-elemen diagonal utama dari matriks $\sum_{d d}$ merupakan nilai ketelitian dari tiap pergerakan titik yang bersesuaian.

$$
\begin{aligned}
& d=\sqrt{\left(X_{t+\Delta t}-X_{t}\right)^{2}+\left(Y_{t+\Delta t}-Y_{t}\right)^{2}+\left(Z_{t+\Delta t}-Z_{t}\right)^{2}} \\
& \sum_{d d}=J_{d} \cdot \sum_{T_{t}, T_{t+\Delta t}} \cdot J_{d}^{T}
\end{aligned}
$$

dengan matriks $\mathrm{J}_{\mathrm{d}}$ adalah matriks Jacobian.

\section{Hasil dan Pembahasan}

\subsection{Kualitas Data Pengamatan dan Kualitas Data Hasil} Pengolahan

1. Kualitas data pengamatan

Parameter kualitas data pengamatan GNSS ditunjukkan dengan nilai MP1 (moving average dari 
multipath sinyal L1), MP2 (moving average dari multipath sinyal L2), IOD slips, dan IOD or MP slips.

Nilai MP1 yang memenuhi kriteria kurang dari 0,5 m hanya terdapat di titik SGH3 kecuali pada doy 231 kala pengamatan 2014, sedangkan pada titik SGH1 dan SGH4 tidak ada nilai yang memenuhi kriteria. Nilai MP2 yang memenuhi kriteria kurang dari 0,5 m hanya terdapat di titik SGH3 kecuali pada kala pengamatan 2014, sedangkan pada titik SGH1 dan SGH4 tidak ada nilai yang memenuhi kriteria. Nilai MP1 dan MP2 yang lebih dari 0,5 m menunjukkan adanya efek multipath yang tidak sedikit pada data pengamatan. Semakin besar nilai MP1 dan MP2, maka semakin besar pula efek multipath yang ada. Kondisi lingkungan sekitar yang memiliki banyak obstruksi dapat mengganggu perambatan sinyal dari satelit ke receiver sehingga menyebabkan nilai multipath cukup tinggi. Nilai multipath yang cukup tinggi pada titik SGH1 dan SGH4 disebabkan oleh kondisi lingkungan yang tidak terbebas dari obstruksi seperti pepohonan dan bangunan.

Nilai IOD slips dan IOD or MP slips yang secara keseluruhan memenuhi kriteria kurang dari 100 hanya terdapat di titik SGH3. Data titik SGH1 memenuhi kriteria kecuali pada kala pengamatan 2016, sedangkan nilai yang memenuhi kriteria pada titik SGH4 hanya terdapat pada kala pengamatan 2015 doy 218. Semakin baik data yang didapatkan mengindikasikan bahwa semakin sedikit efek ionospher delay yang dihasilkan. Besarnya nilai IOD slips dan IOD or MP slips menunjukkan bahwa kondisi atmosfer khususnya pada lapisan ionosfer kurang optimum untuk pengamatan GNSS sehingga menyebabkan keterlambatan sinyal dari satelit ke receiver.

2. Kualitas data hasil pengolahan

Parameter kualitas data hasil pengolahan GAMIT yang berupa data baseline ditunjukkan dengan nilai fract dan postfit nrms, sedangkan parameter kualitas data hasil pengolahan GLOBK yang berupa data koordinat ditunjukkan dengan nilai weighted root mean square (wrms) dan chi square increment per degree of freedom atau nilai statistik $x^{2} / f$. Menurut Herring (2006) hasil pengolahan GAMIT diterima apabila nilai fract kurang dari 10 (fract < 10), sedangkan nilai postfit $n r m s$ harus kurang dari 0,25 (postfit nrms $<0,25$ ). Nilai wrms yang baik dan tidak menunjukkan adanya data outliers berada di bawah $10 \mathrm{~mm}$ (Herring, dkk., 2006). Menurut Lestari (2006), nilai statistik $x^{2} / f$ dianggap konsisten apabila tidak lebih dari 10. Selain dengan melihat nilai wrms dan nilai statistik $x^{2} / f$, kualitas hasil pengolahan GLOBK juga dapat dianalisis dengan melihat nilai simpangan baku pada setiap titik pantau deformasi.

Nilai fract merupakan perbandingan antara nilai adjust dengan nilai formal pada masing-masing komponen koordinat geografis. Nilai fract diperoleh dari pengembangan konsep residual, dimana nilai adjust diperoleh dari selisih antara nilai koordinat pendekatan dengan koordinat hasil perataan. Nilai fract digunakan untuk mendeteksi adanya kesalahan kasar maupun sistematik yang terdapat pada pengolahan GAMIT. Secara keseluruhan, nilai fract berada antara $-1,7$ s.d. 2,2 sehingga seluruh nilai fract dinyatakan diterima karena tidak terdapat nilai yang lebih dari 10. Hal ini menunjukkan bahwa dalam pengolahan GAMIT kala pengamatan tahun 2014, 2015, dan 2016 tidak terdapat kesalahan kasar maupun sistematik.

Nilai postfit nrms merupakan perbandingan nilai varian aposteriori dan varian apriori untuk bobot. Nilai postfit nrms digunakan untuk mengetahui kualitas model pengamatan hasil pengolahan GAMIT. Secara keseluruhan, nilai postfit nrms pada kala pengamatan tahun 2014, 2015, dan 2016 memiliki rentang nilai antara 0,17817 s.d. 0,20535. Berdasarkan nilai postfit nrms tersebut, tidak terdapat satu pun nilai postfit nrms yang memiliki nilai lebih dari 0,25. Hal ini menunjukkan bahwa pemberian bobot apriori sudah benar dan tidak banyak terdapat kesalahan dalam pemodelan sehingga hasil pengolahan GAMIT pada kala pengamatan tahun 2014, 2015, dan 2016 diterima.

Nilai weighted root mean square (wrms) digunakan untuk mengetahui ada tidaknya data outliers. Nilai wrms pada komponen $\mathrm{N}$ dan $\mathrm{E}$ berbeda secara siginifikan dengan nilai wrms pada komponen U. Nilai wrms pada komponen $\mathrm{N}$ dan $\mathrm{E}$ secara keseluruhan berada di bawah $10 \mathrm{~mm}$, sedangkan nilai wrms pada komponen $\mathrm{U}$ berada di atas $10 \mathrm{~mm}$ kecuali pada kala pengamatan 2015. Hal ini menunjukkan bahwa nilai wrms pada komponen $\mathrm{N}$ dan $\mathrm{E}$ memenuhi syarat dan tidak menunjukkan adanya data outliers, sedangkan nilai wrms pada komponen U mengandung data outliers kecuali pada kala pengamatan 2015. Berdasarkan nilai wrms tersebut, dapat diketahui bahwa data terbaik didapatkan pada pengamatan 2015.

Nilai statistik $x^{2} / f$ atau chi square increment per degree of freedom digunakan untuk menentukan konsistensi dari solusi GAMIT terhadap parameter GLOBK yang ditetapkan. Nilai statistik $x^{2} / f$ hasil pengolahan GLOBK pada kala pengamatan 2014, 2015, dan 2016 berkisar antara 0,000 s.d. 2,043. Nilai statistik $x^{2} / f$ tertinggi dan terendah berada pada kala pengamatan 2015 yaitu pada doy 219 dan doy 218 . Dari nilai statistik $x^{2} / f$ tersebut, tidak terdapat nilai yang lebih dari 10. Hal ini menunjukkan bahwa solusi GAMIT konsisten terhadap parameter GLOBK yang ditetapkan sehingga hasil pengolahan GLOBK pada kala pengamatan tahun 2014, 2015, dan 2016 diterima.

\subsection{Koordinat dan Simpangan Baku}


Titik koordinat dalam penelitian ini yaitu titik SGH1 dan SGH3 pada kala pengamatan 2014, sedangkan pada kala pengamatan 2015 dan 2016 menggunakan titik SGH1, SGH3, dan SGH4. Koordinat dan simpangan baku titik pantau pada kala pengamatan tahun 2014, 2015, dan 2016 ditampilkan pada Tabel 3.1 menggunakan sistem koordinat toposentrik.

Tabel 3.1 Koordinat dan simpangan baku

\begin{tabular}{|c|c|c|c|c|c|c|c|}
\hline \multirow[t]{2}{*}{ Tahun } & \multirow[t]{2}{*}{ Titik } & \multicolumn{3}{|c|}{ Koordinat Toposentrik (m) } & \multicolumn{3}{|c|}{$\begin{array}{c}\text { Simpangan Baku } \\
(\mathrm{mm})\end{array}$} \\
\hline & & $\mathbf{N}$ & $\mathbf{E}$ & $\mathbf{U}$ & $\mathbf{N}$ & E & $\mathbf{U}$ \\
\hline \multirow{2}{*}{2014} & SGH1 & 415703,306 & 13934663,137 & 93,240 & 1,20 & 1,47 & 5,14 \\
\hline & SGH3 & 371708,352 & 13954900,124 & 146,962 & 1,02 & 1,26 & 3,81 \\
\hline \multirow{3}{*}{2015} & SGH1 & 415703,308 & 13934663,145 & 93,253 & 1,73 & 2,12 & 7,25 \\
\hline & SGH3 & 371708,343 & 13954900,142 & 146,872 & 1,33 & 1,65 & 4,47 \\
\hline & $\mathrm{SGH} 4$ & 403326,210 & 13936373,006 & 89,392 & 1,50 & 1,88 & 6,06 \\
\hline \multirow{3}{*}{2016} & SGH1 & 415703,305 & 13934663,156 & 93,208 & 1,29 & 1,60 & 5,81 \\
\hline & SGH3 & 371708,343 & 13954900,157 & 146,952 & 0,88 & 1,08 & 3,11 \\
\hline & $\mathrm{SGH} 4$ & 403326,208 & 13936372,995 & 89,397 & 0,99 & 1,24 & 4,13 \\
\hline
\end{tabular}

Pada Tabel 3.1 dilihat bahwa nilai koordinat toposentrik berada dalam satuan meter (m) sedangkan nilai simpangan baku berada dalam satuan milimeter (mm). Nilai simpangan baku pada komponen $\mathrm{N}$ berkisar antara 0,88 s.d. $1,73 \mathrm{~mm}$, komponen E berkisar antara 1,08 s.d. $2,12 \mathrm{~mm}$, dan komponen U berkisar antara 3,11 s.d. 7,25 mm. Berdasarkan nilai simpangan baku terkecil dan terbesar pada komponen N, E, dan U tersebut dapat diketahui bahwa nilai simpangan baku terkecil selalu berada pada kala pengamatan 2016, sedangkan nilai simpangan baku terbesar selalu berada pada kala pengamatan 2015. Semakin besar nilai simpangan baku maka semakin rendah ketelitian yang didapatkan, begitu pula sebaliknya. Berdasarkan hal tersebut dapat diketahui bahwa pengamatan dengan ketelitian tertinggi terjadi pada kala pengamatan 2016, sedangkan pengamatan dengan ketelitian terendah terjadi pada kala pengamatan 2015. Kala pengamatan 2015 menghasilkan ketelitian terendah karena hanya menggunakan dua doy pengamatan, sedangkan kala pengamatan 2014 dan 2016 menggunakan empat doy pengamatan. Kala pengamatan 2016 menghasilkan ketelitian tertinggi karena menggunakan doy pengamatan yang lebih banyak daripada kala pengamatan 2015 dan menggunakan titik pantau yang lebih banyak daripada kala pengamatan 2014 .

Simpangan baku pada komponen U secara signifikan lebih besar daripada simpangan baku pada komponen $\mathrm{N}$ dan E. Hal ini terjadi karena nilai wrms pada komponen U juga secara signifikan lebih besar daripada nilai wrms pada komponen $\mathrm{N}$ dan $\mathrm{E}$ sesuai dengan pembahasan kualitas data hasil pengolahan tentang nilai wrms. Pembahasan kualitas data hasil pengolahan tentang nilai wrms menunjukkan bahwa komponen $\mathrm{N}$ dan $\mathrm{E}$ memenuhi syarat dan tidak menunjukkan adanya data outliers, sedangkan pada komponen $U$ tidak memenuhi syarat dan mengandung data outliers. Data outliers (loncatan data) terjadi karena adanya bias pada troposfer yang menyebabkan ketelitian tinggi (komponen U) GNSS menjadi lebih rendah. Selain karena nilai wrms, besarnya simpangan baku pada komponen U juga disebabkan oleh faktor geometri satelit yang tidak memungkinkan pengamatan di bawah horizon, sehingga kekuatan ikatan jaring untuk komponen tinggi GNSS menjadi lebih lemah.

Berdasarkan Tabel 3.1 diketahui bahwa simpangan baku setiap komponen titik SGH3 dalam kala pengamatan yang sama selalu lebih kecil daripada simpangan baku titik SGH1. Hal ini sesuai dengan pengecekan kualitas data yang menunjukkan bahwa kualitas data titik SGH3 selalu lebih baik daripada titik SGH1. Pengecekan kualitas data menunjukkan bahwa nilai MP1, MP2, IOD slips, dan IOD or MP slips dari titik SGH3 lebih baik daripada titik SGH1.

\subsection{Analisis Pergerakan Metode Perhitungan Periodik}

Analisis pergerakan metode periodik berdasarkan nilai kecepatan dan simpangan baku metode periodik. Perhitungan kecepatan pergerakan metode periodik kala 2014 ke 2015 dan 2015 ke 2016 beserta simpangan bakunya berdasarkan prinsip Kalman Filtering menggunakan GAMIT/GLOBK. Selanjutnya perhitungan kecepatan pergerakan metode periodik kala 2014 ke 2016 dilakukan dengan menghitung rata-rata kecepatan pergerakan dari dua hasil perhitungan GAMIT/GLOBK, sedangkan simpangan baku metode periodik kala 2014 ke 2016 dihitung dengan rumus perambatan kesalahan. Pergerakan horizontal didapatkan dari nilai resultan komponen $\mathrm{N}$ dan $\mathrm{E}$, sedangkan pergerakan vertikal ditunjukkan oleh nilai pada komponen U. Hasil perhitungan kecepatan pergerakan kala pengamatan 2014 ke 2015, 2015 ke 2016, dan 2014 ke 2016 metode periodik ditampilkan pada Tabel 3.2 . 
Tabel 3.2 Kecepatan pergerakan menggunakan metode perhitungan periodik

\begin{tabular}{|c|c|c|c|c|c|c|c|c|c|}
\hline \multirow{2}{*}{ Kala } & \multirow{2}{*}{ Titik } & \multicolumn{4}{|c|}{ Kecepatan (mm/tahun) } & \multicolumn{3}{|c|}{$\begin{array}{c}\text { Simpangan Baku } \\
\text { (mm/tahun) }\end{array}$} & \multirow{2}{*}{ Azimuth } \\
\hline & & $\mathbf{N}$ & $\mathbf{E}$ & $\mathbf{U}$ & $\mathrm{Hz}$ & $\mathbf{N}$ & $\mathbf{E}$ & $\mathbf{U}$ & \\
\hline $\begin{array}{c}2014 \\
\mathrm{ke}\end{array}$ & SGH1 & 1,46 & 6,97 & 14,19 & 7,12 & 2,41 & 2,98 & 10,32 & $78^{0} 10^{\prime} 9,68^{\prime \prime}$ \\
\hline 2015 & SGH3 & $-9,68$ & 17,04 & $-92,82$ & 19,60 & 1,88 & 2,37 & 6,67 & $119^{0} 35^{\prime} 59,38^{\prime \prime}$ \\
\hline $\begin{array}{c}2015 \\
\text { ke }\end{array}$ & SGH1 & $-3,68$ & 11,44 & $-44,22$ & 12,02 & 2,25 & 2,79 & 9,80 & $107^{0} 49^{\prime} 54,69^{\prime \prime}$ \\
\hline 2016 & SGH3 & $-0,18$ & 15,95 & 79,44 & 15,95 & 1,65 & 2,06 & 5,76 & $90^{\circ} 38^{\prime} 47,65^{\prime \prime}$ \\
\hline $\begin{array}{c}2014 \\
\text { ke }\end{array}$ & SGH1 & $-1,11$ & 9,21 & $-15,02$ & 9,28 & 2,72 & 4,17 & 50,64 & $96^{0} 52^{\prime} 19,95^{\prime \prime}$ \\
\hline 2016 & SGH3 & $-4,93$ & 16,50 & $-6,69$ & 17,22 & 1,56 & 2,47 & 19,42 & $106^{0} 38^{\prime} 7,83^{\prime \prime}$ \\
\hline
\end{tabular}

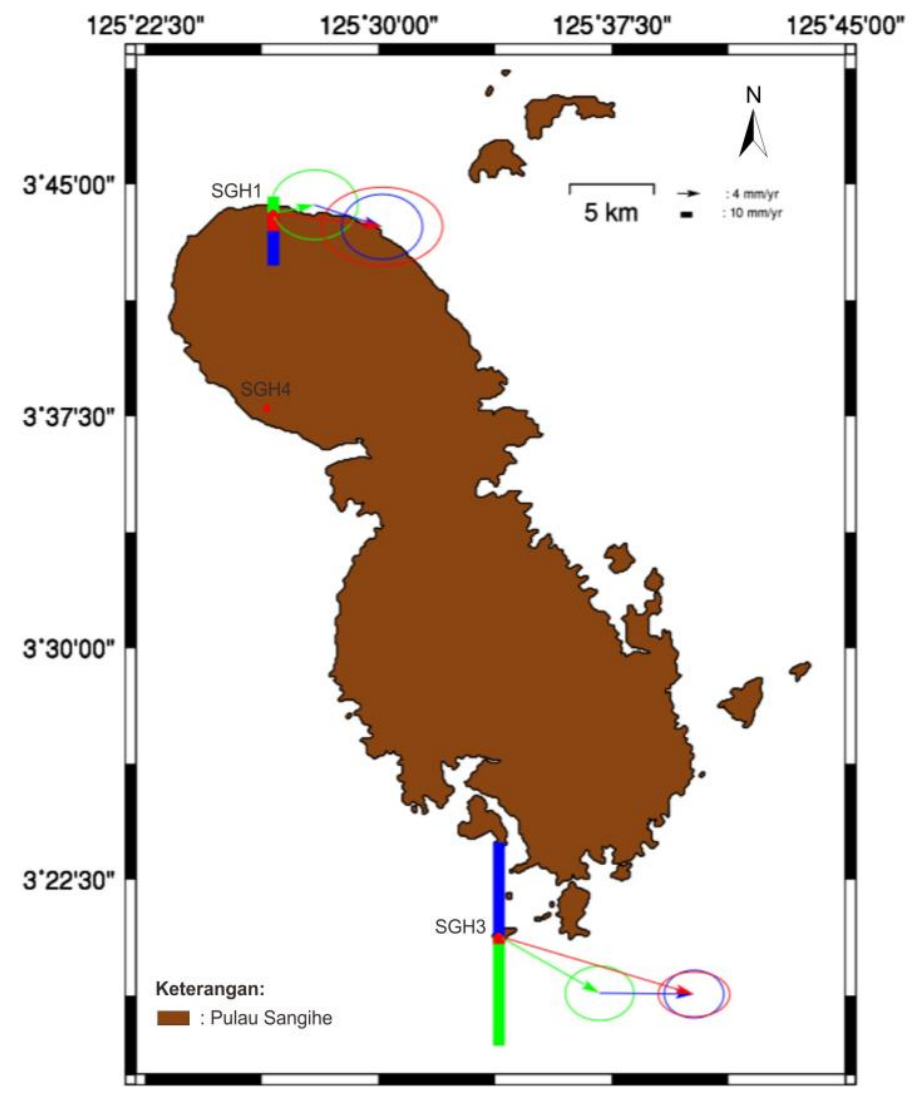

Gambar 3.2 Visualisasi pergerakan horizontal dan vertikal metode periodik

Pada Tabel 3.2 dapat dilihat bahwa nilai kecepatan pergerakan metode periodik berkisar antara 0,18 $\mathrm{mm} /$ tahun s.d. 92,82 $\mathrm{mm} /$ tahun. Nilai kecepatan terbesar berada pada kala pengamatan 2014 ke 2015 di titik SGH3 komponen U yang mengalami penurunan sebesar 92,82 $\mathrm{mm} /$ tahun, sedangkan nilai kecepatan terkecil berada pada kala pengamatan 2015 ke 2016 di titik SGH1 komponen $\mathrm{N}$ dengan nilai $0,18 \mathrm{~mm} /$ tahun ke arah selatan.

Berdasarkan Tabel 3.2 dapat diketahui bahwa nilai kecepatan pergerakan metode periodik kala pengamatan 2014 ke 2015 pada komponen vertikal di titik SGH1 mengalami kenaikkan sebesar 14,19 mm/tahun, sedangkan titik SGH3 mengalami penurunan sebesar $92,82 \mathrm{~mm} /$ tahun. Berdasarkan komponen horizontal dapat diketahui bahwa titik SGH1 mengalami pergerakan sebesar 7,12 mm/tahun dengan azimuth $78^{\circ} 10^{\prime}$ 9,68", sedangkan titik SGH3 mengalami pergerakan sebesar $19,60 \mathrm{~mm} /$ tahun dengan azimuth $119^{\circ} 35^{\prime}$ 59,38".

Berdasarkan Tabel 3.2 juga dapat diketahui bahwa nilai kecepatan pergerakan metode periodik kala pengamatan 2015 ke 2016 pada komponen vertikal di titik SGH1 mengalami penurunan sebesar 44,22 mm/tahun, sedangkan titik SGH3 mengalami kenaikkan sebesar 79,44 $\mathrm{mm} /$ tahun. Berdasarkan komponen horizontal dapat diketahui bahwa titik SGH1 mengalami pergerakan sebesar 12,02 mm/tahun dengan azimuth $107^{\circ} 49^{\prime} 54,69^{\prime \prime}$, sedangkan titik SGH3 mengalami pergerakan sebesar $15,95 \mathrm{~mm} /$ tahun dengan azimuth $90^{\circ} 38^{\prime} 47,65^{\prime \prime}$.

Berdasarkan Tabel 3.2 juga dapat diketahui bahwa nilai kecepatan pergerakan metode periodik kala pengamatan 2014 ke 2016 pada komponen vertikal di titik SGH1 mengalami penurunan sebesar $15,02 \mathrm{~mm} /$ tahun, sedangkan titik SGH3 mengalami penurunan sebesar 6,69 $\mathrm{mm} /$ tahun. Berdasarkan komponen horizontal dapat diketahui bahwa titik SGH1 mengalami pergerakan sebesar 9,28 mm/tahun dengan azimuth $96^{\circ} 52^{\prime} 19,95^{\prime \prime}$, sedangkan titik SGH3 mengalami pergerakan sebesar $17,22 \mathrm{~mm} /$ tahun dengan azimuth $106^{\circ} 38^{\prime} \quad 7,83^{\prime \prime}$. Visualisasi kecepatan pergerakan horizontal dan vertikal metode periodik ditampilkan pada Gambar 3.2.

Pada Gambar 3.2 warna hijau merupakan visualisasi pergerakan horizontal dan vertikal metode periodik kala pengamatan 2014 ke 2015, warna biru merupakan visualisasi pergerakan horizontal dan vertikal metode periodik kala pengamatan 2015 ke 2016, dan warna merah merupakan visualisasi pergerakan horizontal dan vertikal metode periodik kala pengamatan 2014 ke 2016.

Tabel 3.2 menunjukkan ketelitian pergerakan berdasarkan nilai simpangan baku pergerakan dari setiap titik pada komponen N, E, dan U. Semakin kecil nilai simpangan baku maka semakin tinggi ketelitian yang didapatkan, begitu pula sebaliknya semakin besar nilai simpangan baku maka semakin rendah ketelitian yang didapatkan. Simpangan baku pergerakan terkecil kala pengamatan 2014 ke 2015 terdapat di titik SGH3 pada

JGISE Vol. 3 No. 1 (2020) | doi:10.22146/jgise. 53068 | https://jurnal.ugm.ac.id/jgise 
komponen $\mathrm{N}$ dengan nilai 1,88 $\mathrm{mm} /$ tahun, sedangkan simpangan baku pergerakan terbesar terdapat di titik SGH1 pada komponen U dengan nilai $10,32 \mathrm{~mm} /$ tahun. Simpangan baku pergerakan terkecil kala pengamatan 2015 ke 2016 terdapat di titik SGH3 pada komponen N dengan nilai $1,65 \mathrm{~mm} /$ tahun, sedangkan simpangan baku pergerakan terbesar terdapat di titik SGH1 pada komponen U dengan nilai 9,80 mm/tahun. Simpangan baku pergerakan terkecil kala pengamatan 2014 ke 2016 terdapat di titik SGH3 pada komponen N dengan nilai 1,56 $\mathrm{mm} /$ tahun, sedangkan simpangan baku pergerakan terbesar terdapat di titik SGH1 pada komponen U dengan nilai 50,64 mm/tahun. Ketelitian pergerakan komponen U pada kala pengamatan 2014 ke 2016 secara signifikan lebih rendah daripada ketelitian pergerakan komponen $U$ pada kala pengamatan lainnya karena penghitungan ketelitian metode periodik kala pengamatan 2014 ke 2016 dihitung dengan rumus perambatan kesalahan. Nilai simpangan baku pergerakan terkecil selalu terdapat di titik SGH3 pada komponen N, sedangkan nilai simpangan baku pergerakan terbesar selalu terdapat di titik SGH1 pada komponen U. Berdasarkan hal ini dapat diketahui bahwa ketelitian pergerakan tertinggi terdapat di titik SGH3 pada komponen N, sedangkan ketelitian pergerakan terendah terdapat di titik SGH1 pada komponen U.
Pergerakan titik SGH3 memiliki ketelitian yang lebih tinggi daripada pergerakan titik SGH1 sesuai dengan pembahasan kualitas data pengamatan dan pembahasan koordinat dan simpangan baku. Pembahasan koordinat dan simpangan baku menunjukkan nilai simpangan baku titik SGH3 selalu lebih kecil daripada titik SGH1 dan pembahasan kualitas data pengamatan menunjukkan pengecekan kualitas data titik SGH3 selalu lebih baik daripada titik SGH1. Pengecekan kualitas data menunjukkan bahwa nilai MP1, MP2, IOD slips, dan IOD or MP slips titik SGH3 lebih baik daripada titik SGH1.

\subsection{Analisis Pergerakan Metode Perhitungan Simultan}

Analisis pergerakan metode simultan dilakukan berdasarkan nilai kecepatan dan simpangan baku metode simultan. Perhitungan kecepatan pergerakan metode simultan dan simpangan bakunya dilakukan dengan menghitung secara serentak pergerakan kala pengatamatan 2014 ke 2016 berdasarkan prinsip Kalman Filtering dengan GAMIT/GLOBK. Pergerakan horizontal didapatkan dari nilai resultan komponen $\mathrm{N}$ dan $\mathrm{E}$, sedangkan pergerakan vertikal ditunjukkan oleh nilai pada komponen U. Hasil perhitungan kecepatan pergerakan kala pengamatan 2014 ke 2016 metode simultan ditampilkan pada Tabel 3.3.

Tabel 3.3 Kecepatan pergerakan menggunakan metode perhitungan simultan

\begin{tabular}{|c|c|c|c|c|c|c|c|c|}
\hline \multirow{2}{*}{ Titik } & \multicolumn{4}{|c|}{ Kecepatan (mm/tahun) } & \multicolumn{3}{|c|}{$\begin{array}{c}\text { Simpangan Baku } \\
\text { (mm/tahun) }\end{array}$} & \multirow{2}{*}{ Azimuth } \\
\hline & $\mathbf{N}$ & $\mathbf{E}$ & $\mathbf{U}$ & $\mathbf{H z}$ & $\mathbf{N}$ & $\mathbf{E}$ & $\mathbf{U}$ & \\
\hline SGH1 & $-1,56$ & 9,40 & $-11,54$ & 9,53 & 1,25 & 1,55 & 5,83 & $99^{0} 25^{\prime} 22,01^{\prime \prime}$ \\
\hline SGH3 & $-5,18$ & 16,91 & $-2,84$ & 17,69 & 0,88 & 1,10 & 3,49 & $107^{0} 1^{\prime} 52,58^{\prime \prime}$ \\
\hline
\end{tabular}

Pada Tabel 3.3 dapat dilihat bahwa nilai kecepatan pergerakan kala pengamatan 2014 ke 2016 metode simultan berkisar antara 1,56 $\mathrm{mm} /$ tahun s.d. 16,91 $\mathrm{mm} /$ tahun. Nilai kecepatan terbesar berada di titik SGH3 pada komponen E dengan nilai $16,91 \mathrm{~mm} /$ tahun yang bergerak ke arah timur, sedangkan nilai kecepatan terkecil berada di titik SGH1 pada komponen N dengan nilai 1,56 $\mathrm{mm} /$ tahun yang bergerak ke arah selatan. Berdasarkan komponen vertikal dapat diketahui bahwa titik SGH1 mengalami penurunan sebesar 11,54 $\mathrm{mm} /$ tahun, sedangkan titik SGH3 mengalami penurunan sebesar 2,84 $\mathrm{mm} /$ tahun. Berdasarkan komponen horizontal dapat diketahui bahwa titik SGH1 mengalami pergerakan sebesar 9,53 mm/tahun dengan azimuth $99^{\circ} 25^{\prime} 22,01^{\prime \prime}$, sedangkan titik SGH3 mengalami pergerakan sebesar $17,69 \mathrm{~mm} /$ tahun dengan azimuth $107^{0} 1^{\prime}$ 52,58". Visualisasi kecepatan pergerakan horizontal dan vertikal metode simultan ditampilkan pada Gambar 3.3.

Tabel 3.3 menunjukkan ketelitian pergerakan berdasarkan nilai simpangan baku pergerakan dari setiap titik pada komponen N, E, dan U. Ketelitian paling tinggi terjadi di titik SGH3 pada komponen $\mathrm{N}$ dengan nilai 0,88 $\mathrm{mm} /$ tahun, sedangkan ketelitian paling rendah terjadi di titik SGH1 pada komponen U dengan nilai 5,83 mm/tahun. Berdasarkan Tabel 3.3 dapat diketahui bahwa titik SGH3 memiliki ketelitian yang lebih tinggi daripada titik SGH1 karena nilai simpangan baku pada setiap komponen di titik SGH3 lebih rendah daripada nilai simpangan baku di titik SGH1. Hal ini sesuai dengan pembahasan kualitas data pengamatan dan pembahasan koordinat dan simpangan baku. Pembahasan koordinat dan simpangan baku menunjukkan nilai simpangan baku koordinat titik SGH3 selalu lebih kecil daripada titik SGH1 dan pembahasan kualitas data pengamatan menunjukkan pengecekan kualitas data titik SGH3 selalu lebih baik daripada titik SGH1. Pengecekan kualitas data menunjukkan bahwa nilai MP1, MP2, IOD slips, dan IOD or MP slips dari titik SGH3 lebih baik daripada titik SGH1. 


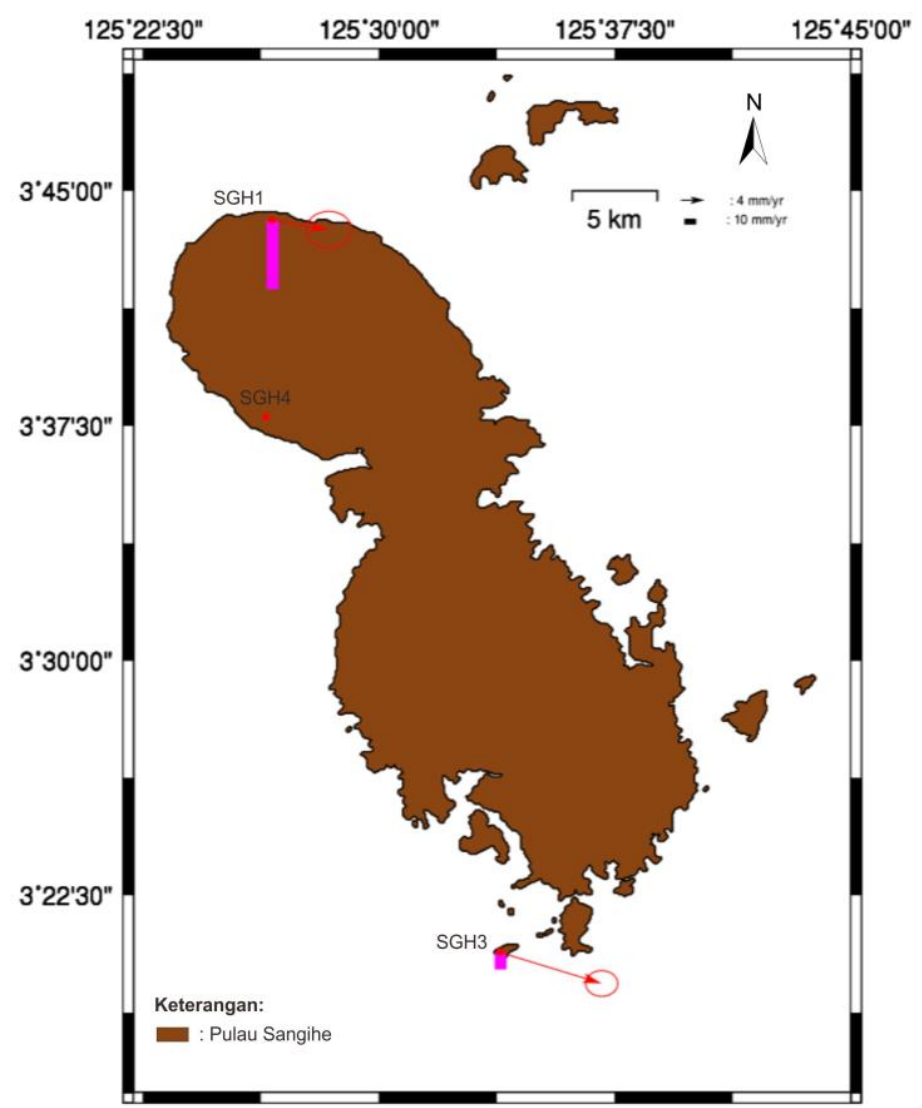

Gambar 3.3 Visualisasi pergerakan horizontal dan vertikal metode simultan

\subsection{Analisis Ketelitian Pergerakan Metode Perhitungan Periodik dan Simultan}

Analisis ketelitian pergerakan metode periodik dan simultan dilakukan dengan membandingkan nilai simpangan baku. Metode analisis perbandingan dilakukan dengan uji signifikansi beda dua parameter dan analisis besar ketelitian secara grafis.

1. Uji signifikansi beda dua parameter

Uji signifikansi beda dua parameter dilakukan untuk mengetahui apakah nilai pergerakan metode periodik dan simultan berbeda secara signifikan. Pengujian dilakukan dengan membandingkan nilai $t_{x}$ hasil hitungan dengan nilai $t$ pada tabel $t$-student. Tingkat kepercayaan yang digunakan untuk uji signifikansi beda dua parameter pada penelitian ini yaitu $95 \%$ atau level of significance 5\% dengan derajat kepercayaan tak hingga $(r=\infty)$ sehingga diperoleh nilai $t$ pada tabel $t$-student sebesar 1,96. Pengujian diterima apabila nilai $t_{x}$ kurang dari nilai $t$ pada tabel t-student. Hasil uji signifikansi beda dua parameter pergerakan ditampilkan pada Tabel 3.4.
Tabel 3.4 Hasil uji signifikansi beda dua parameter pergerakan

\begin{tabular}{cccc}
\hline Titik & Komponen & Nilai t & Hasil Uji \\
\hline \multirow{2}{*}{ SGH1 } & $\mathrm{V}_{\mathrm{N}}$ & 0,15033 & Diterima \\
& $\mathrm{V}_{\mathrm{E}}$ & 0,04271 & Diterima \\
& $\mathrm{V}_{\mathrm{U}}$ & 0,06827 & Diterima \\
& $\mathrm{V}_{\mathrm{N}}$ & 0,13958 & Diterima \\
$\mathrm{SGH3}$ & $\mathrm{V}_{\mathrm{E}}$ & 0,15163 & Diterima \\
& $\mathrm{V}_{\mathrm{U}}$ & 0,19512 & Diterima \\
\hline
\end{tabular}

Pada Tabel 3.4 dapat dilihat bahwa semua hasil uji signifikansi beda dua parameter diterima. Hal ini menunjukkan bahwa nilai pergerakan metode periodik dan simultan tidak berbeda secara signifikan.

\section{Analisis grafis}

Analisis grafis dilakukan berdasarkan ketelitian pergerakan metode periodik dan simultan. Besar ketelitian pergerakan direpresentasikan oleh nilai simpangan baku pergerakan. Semakin besar nilai simpangan baku maka semakin rendah ketelitian pergerakan, begitu pula sebaliknya semakin kecil nilai simpangan baku maka semakin tinggi ketelitian pergerakan. Simpangan baku tersebut divisualisasikan dalam bentuk grafik bar. Perbandingan nilai simpangan baku antar komponen (N, E, U) dan perbandingan nilai simpangan baku metode periodik dan simultan masing-masing divisualisasikan dalam Gambar 3.4 dan 3.5.

Pada Gambar 3.4 dapat dilihat bahwa setiap komponen pergerakan memiliki nilai simpangan baku yang bervariasi. Berdasarkan Gambar 3.4 dapat diketahui bahwa nilai simpangan baku pergerakan pada komponen $U$ selalu lebih besar daripada komponen $\mathrm{N}$ dan $\mathrm{E}$. Hal ini mengindikasikan bahwa ketelitian pergerakan pada komponen U lebih rendah daripada ketelitian pergerakan pada komponen $\mathrm{N}$ dan E. Rendahnya ketelitian pada komponen $U$ sesuai dengan pembahasan kualitas data hasil pengolahan tentang nilai wrms dan pembahasan koordinat dan simpangan baku. Pembahasan koordinat dan simpangan baku menunjukkan nilai simpangan baku koordinat komponen $\mathrm{N}$ dan $\mathrm{E}$ selalu lebih kecil daripada komponen $\mathrm{U}$ dan pembahasan kualitas data hasil pengolahan menunjukkan nilai wrms pada komponen $\mathrm{N}$ dan $\mathrm{E}$ secara signifikan lebih kecil daripada nilai wrms pada komponen U. Berdasarkan nilai wrms diketahui bahwa komponen $\mathrm{N}$ dan $\mathrm{E}$ memenuhi syarat dan tidak menunjukkan adanya data 
outliers, sedangkan pada komponen U tidak memenuhi syarat dan mengandung data outliers. Data outliers (loncatan data) yang terjadi pada komponen $U$ disebabkan oleh bias pada troposfer yang mengakibatkan ketelitian tinggi GNSS menjadi lebih rendah. Selain karena data outliers, rendahnya ketelitian pada komponen U juga disebabkan oleh faktor geometri satelit yang tidak memungkinkan pengamatan di bawah horizon, sehingga kekuatan ikatan jaring untuk komponen tinggi GNSS menjadi lebih lemah.

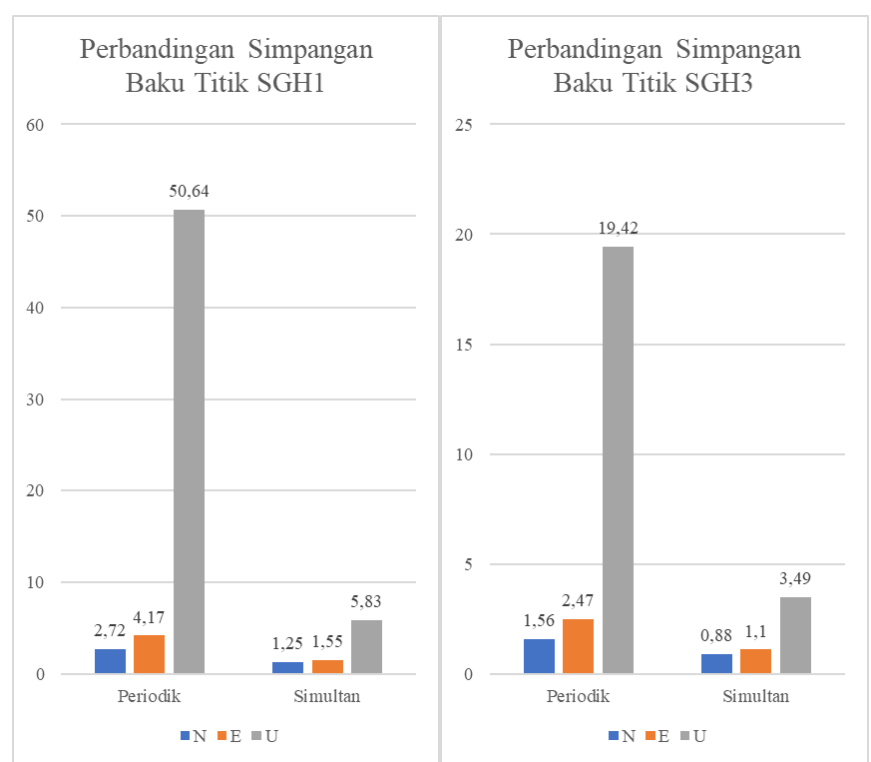

Gambar 3.4 Perbandingan nilai simpangan baku antar komponen dalam satuan centimeter $(\mathrm{cm})$

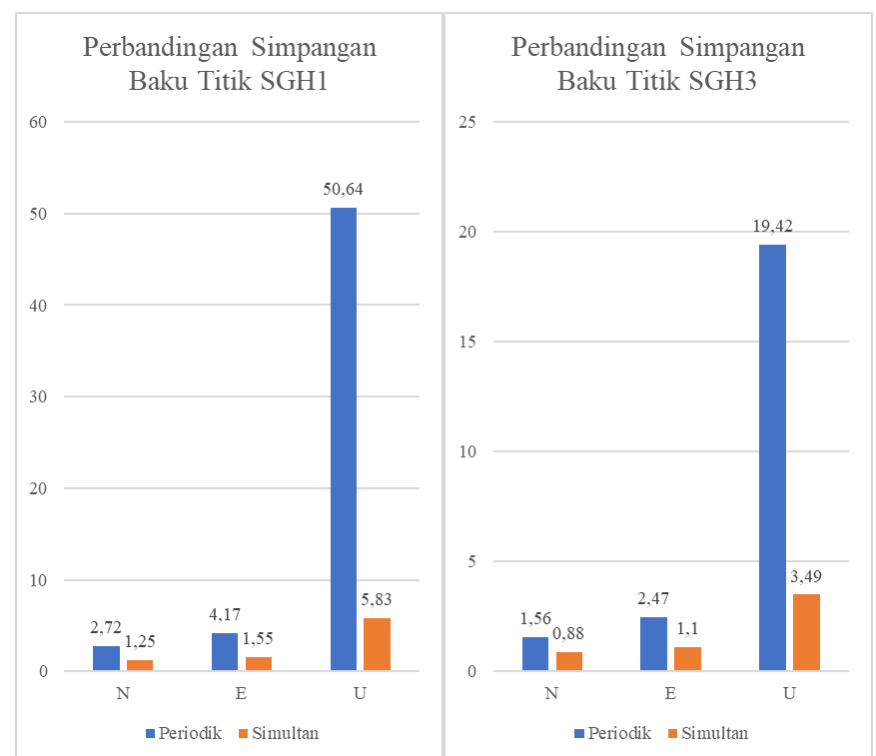

Gambar 3.5 Perbandingan nilai simpangan baku metode periodik dan simultan dalam satuan centimeter $(\mathrm{cm})$
Berdasarkan Gambar 3.5 dapat diketahui bahwa setiap komponen pada metode periodik memiliki nilai simpangan baku pergerakan yang lebih besar daripada metode simultan. Hal ini mengindikasikan bahwa ketelitian pergerakan metode periodik lebih rendah daripada ketelitian pergerakan metode simultan.

\section{Kesimpulan}

Dari penelitian ini dapat diketahui bahwa ketelitian pergerakan metode periodik lebih rendah daripada ketelitian pergerakan metode simultan. Hal ini ditunjukkan dengan nilai simpangan baku metode periodik yang selalu lebih besar daripada nilai simpangan baku metode simultan. Selain itu, ketelitian pergerakan pada komponen $\mathrm{N}$ dan $\mathrm{E}$ secara signifikan lebih tinggi daripada ketelitian pergerakan pada komponen $\mathrm{U}$. Komponen U memiliki ketelitian yang lebih rendah daripada komponen $\mathrm{N}$ dan $\mathrm{E}$ karena mengandung lebih banyak data outliers yang ditunjukkan dengan besarnya nilai wrms. Walaupun demikian, nilai pergerakan metode periodik dan simultan tidak berbeda secara signifikan. Hal ini terjadi karena hasil uji signifikansi beda dua parameter pada setiap komponen pergerakan diterima.

\section{Pernyataan Konflik Kepentingan}

Penulis menyatakan tidak ada konflik kepentingan dalam artikel ini (The authors declare no competing interest).

\section{Referensi}

Abidin, H. Z. (2000). Penentuan posisi dengan GPS dan aplikasinya. Jakarta: PT Pradnya Paramita.

Afzal, M. (2015). Analisis Gerakan Titik Pantau Anjungan Minyak Lepas Pantai Menggunakan Data Pengamatan GPS. Skripsi, Departemen Teknik Geodesi Universitas Gadjah Mada, Yogyakarta.

BAPPEDA. (2009). Profil Sangihe 2009. https://id.scribd.com/doc/30958100/ProfilSangihe-2009 (diakses tanggal 14 September 2019).

Darman, H., \& Sidi, F. H. (2000). An outline of the geology of Indonesia. Indonesian Association of Geologists, Jakarta, 192.

Herring, T. A., King, R. W., \& McClussky, S. C. (2006). Introduction to GAMIT/GLOBK. Department of Earth, Atmospheric, and Planetary Science. Massachusetts Institute of Technology.

King, R.W. \& Bock, Y.K. (2002) Documentation for the GAMIT GPS Analysis Software. Department of Earth, Atmospheric, and Planetary Sciences, Massachusetts Institue of Technology and Scripts Institute of Oceanography, University of California at San Diego, USA. 
Kurniawan, M.G. (2016). Analisis Deformasi Kepulauan Sangihe Berdasarkan Data Pengukuran GNSS Epoch 2014 dan Epoch 2015. Skripsi, Departemen Teknik Geodesi Universitas Gadjah Mada, Yogyakarta.

Ladivanov, F. (2018). Analisis Deformasi Kepulauan Sangihe Berdasarkan Data Pengukuran GNSS Epoch 2014, 2015, 2016, dan 2017. Skripsi, Departemen Teknik Geodesi Universitas Gadjah Mada, Yogyakarta.

Lestari, D. (2006). GPS Study for Resolving the Stability of Borobudur Tempel Site. Tesis, University of New South Wales,: Sydney.

Lestari, D. (2015). Analisis Stabilitas Candi Borobudur Berdasar Integrasi Data Pengamatan GPS dan Terestris Jaring Pemantau Deformasi Candi. Disertasi, Universitas Gadjah Mada, Yogyakarta.

Manfré, L. A., Hirata, E., Silva, J. B., Shinohara, E. J., Giannotti, M. A., Larocca, A. P. C., \& Quintanilha, J. A. (2012). An analysis of geospatial technologies for risk and natural disaster management. ISPRS
International Journal of Geo-Information, 1(2), 166185.

Nugraha, S. (2017). Analisis Pergerakan Kepulauan Sangihe Berdasarkan Tiga Kala Pengamatan Data Pengukuran GNSS Tahun 2014, 2015, dan 2016. Skripsi, Jurusan Teknik Geodesi, Universitas Gadjah Mada, Yogyakarta.

Nugroho, K,F. (2019). Analisis Deformasi Kepulauan Sangihe Berdasarkan Data Pengukuran GNSS Epoch 2015, 2016, 2017, dan 2018. Skripsi, Jurusan Teknik Geodesi, Universitas Gadjah Mada, Yogyakarta.

Nursetiyadi, R. (2015). Pengaruh Geometri Jaringan IGS terhadap Ketelitian Koordinat Titik Pantau Geodinamika Kepulauan Sangihe Epoch 2014. Skripsi, Jurusan Teknik Geodesi, Universitas Gadjah Mada, Yogyakarta. 